\title{
Peningkatan Kompetensi Pembelajaran Matematika Melalui Rumus Cepat Integral Bagi Siswa Ma Al Falak
}

\author{
Isti Kamila, Maya Widyastiti, Ani Andriyati, Embay Rohaeti \\ Program Studi Matematika, Universitas Pakuan, Indonesia \\ Email corresponding authors: istikamila@unpak.ac.id
}

\begin{abstract}
ABSTRAK
Madrasah Aliyah Al Falak adalah suatu lembaga pendidikan yang berada di Kota Bogor. Berdasarkan informasi dari guru matematika madrasah tersebut, permasalahan yang terjadi di madrasah ini adalah rata-rata nilai matematika siswa tergolong rendah yaitu 50 yang masih dibawah KKM yaitu 60. Hal ini menjadikan kami para tim pelaksana pengabdian untuk melakukan pelatihan rumus cepat integral sehingga dapat meningkatkan minat siswa untuk belajar integral dan meningkatkan kompetensi pembelajaran matematika khususnya pada materi integral. Sebelum dilakukan pelatihan rumus cepat integral, diberikan pretest untuk melihat kemampuan awal siswa dan diperoleh rata-rata pretest adalah 31 . Selanjutnya dilakukan pelatihan rumus cepat integral dan diakhiri dengan pemberian posttest. Berdasarkan hasil posttest, diperoleh nilai rata-rata siswa meningkat menjadi 80.75 dan setelah dilakukan uji-t berpasangan diperoleh $t_{\text {hitung }}=-87.179<-\mathrm{t}_{\text {tabel }}=-0.209302$ maka $t_{\text {hitung }}$ terletak pada daerah $\mathrm{H}_{0}$ ditolak. Oleh karena itu, bisa disimpulkan ada perbedaan nilai antara sebelum dan sesudah pemberian pelatihan rumus cepat integral.
\end{abstract}

Kata Kunci: Rumus Cepat Integral

\section{PENDAHULUAN}

Madrasah Aliyah Al Falak adalah suatu lembaga pendidikan yang berada di wilayah Bogor Barat Kota Bogor. MA Al Falak ini merupakan lembaga pendidikan yang sedang berkembang. Berdasarkan hasil wawancara dengan salah satu guru matematika MA Al Falak yang bernama Bapak Habibi, kami mendapatkan informasi bahwa nilai rata-rata matematika pada materi integral siswa lembaga ini masih tergolong rendah karena dibawah KKM. Nilai rata-rata siswa 50 sedangkan KKM nya 60. Hal ini disebabkan konsep matematika yang diajarkan oleh guru matematika di sekolah ini tidak mendalam dan metode pengajaran yang digunakan oleh para guru masih bersifat konvensional yaitu dengan metode ceramah.

Para siswa MA Al Falak menganggap matematika masih menjadi momok bagi mereka. Lembaga ini kami jadikan mitra karena selain untuk meningkatkan nilai rata-rata matematika tahun ajaran 2019/2020 juga sebagai tempat pertama kali pengajaran modul rumus cepat integral sehingga dapat berkelanjutan untuk diajarkan pada semua murid di tahun ajaran berikutnya. Lembaga ini merupakan pusat pendidikan, sehingga modul rumus cepat ini akan dengan mudah disebarluaskan kepada masyarakat luas yang membutuhkan.

Program ini dapat memberikan nilai tambah jika ditinjau dari dua sisi. Pertama, melalui program pelatihan metode rumus cepat integral ini, guru dapat mengajarkan konsep integral secara menarik sehingga dapat meningkatkan nilai matematika siswa pada ujian nasiona. Kedua, modul dapat disebarluaskan ke seluruh sekolah yang mengalami kendala yang sama sehingga tercapai pemerataan peningkatan nilai matematika pada ujian nasional untuk seluruh sekolah yang membutuhkan. 
Berdasarkan analisis situasi, permasalahan yang dialami mitra dapat dirumuskan sebagai berikut:

1. Nilai rata-rata siswa MA Al Falak tahun ajaran 2018/2019 dibawah nilai KKM, yaitu nilai rata-rata 50 sedangkan nilai KKM 60.

2. Metode mengajar guru masih bersifat konvensional yaitu metode ceramah. Masalah prioritas ditentukan dengan melihat dan mengkaji masalah yang belum didapatkan solusi signifikan untuk mengatasinya.

Berdasarkan hal tersebut maka disepakati antara tim pengusul dan mitra, masalah prioritas yaitu perlu ada metode lain untuk mengajarkan konsep integral kepada siswa. Adapun metode yang digunakan adalah memberikan rumus cepat integral yang diharapkan dapat membuat siswa MA Al Falak termotivasi untuk mempelajari integral. Meskipun begitu, tim pelaksana PKM tetap mengajarkan konsep dasar yang formal. Setelah itu baru diajarkan cara cepat integralnya.

\section{METODE PELAKSANAAN}

Solusi permasalahan prioritas mitra yaitu dengan memberikan metode lain untuk mengajarkan konsep integral kepada siswa sehingga dapat meningkatkan minat siswa untuk belajar integral lebih mendalam. Menurut Muhibbin (2006) minat adalah kecenderungan dan kegairahan yang tinggi atau keinginan yang besar terhadap sesuatu. Adapun metode yang digunakan untuk meningkatkan minat belajar siswa untuk belajar konsep integral adalah metode rumus cepat.

Pandemi Covid 19 yang terjadi sejak awal perencanaan pelaksanaan kegian pengabdian mengakibatkan diundurnya pelasanaan pengabdian sehingga tidak sesuai dengan rencana di awal. Hal ini dikarenakan pihak sekolah menon-aktifkan kegiatan pembelajaran tatap muka di sekolah dan beralih ke pembelajaran secara daring. Berdasarkan hal itu, pihak sekolah meminta kami untuk menunggu waktu yang tepat untuk megizinkan tim pelaksana melakukan pelaksanaan pengabdian secara tatap muka. Tanggal 20 agustus 2020 pihak sekolah mengijinkan kami untuk melakukan pelaksanaan pengabdian, namun karena peraturan tidak boleh berkerumun, kami hanya boleh mengajar 20 siswa kelas XII. Kami pun menerimanya. Namun, pada tanggal 19 Agustus 2020, pihak sekolah memberikan informasi bahwa ada siswa yang terjangkit covid19 sehingga pihak sekolah harus menonaktifkan kembali kegiatan di sekolah dan mengakibatkan tim pelaksana batal melaksanakan PKM pada tanggal 20 agustus 2020 padahal tim pelaksana sudah mencetak modul, membeli face shield dan hand sanitizer untuk tim pelaksana, guru dan siswa serta membeli hadiah untuk siswa yang bisa menjawab benar. Oleh karena itu, modul, face shield, hand sanitizer dan hadiah kami serahkan ke sekolah dengan bantuan kurir.

Pelaksanaan PKM yang selalu dibatalkan menyebabkan kami bernegosiasi kembali ke wakil kepala sekolah untuk mengijinkan kami melaksanakan PKM secara daring. Wakil kepala sekolah menginformasikan adanya kendala dalam daring, yaitu kondisi ekonomi keluarga siswa MA Al Falak tergolong menengah ke bawah sehingga mereka tidak mampu untuk membeli pulsa bahkan ada yang dalam 1 keluarga itu hanya memiliki $1 \mathrm{hp}$ yang dipakai ayahnya yang bekerja sehingga sang anak tidak bisa menggunakan hp untuk belajar sebelum ayahnya pulang kerja. Akhirnya, tim pelaksana memutuskan untuk membeli pulsa bagi 1 orang guru matematika dan 20 orang yang kemampuannya sama untuk mengikuti pelatihan rumus cepat integral.

Berdasarkan permasalahan sebelum pandemik dan pada saat pandemik, maka terdapat beberapa langkah yang dilakukan sebagai solusi, yaitu:

1. Memberikan Pretest dalam bentuk Google Form

2. Memberikan video pembelajaran dan modul cepat integral melalui WhatsApp

3. Melaksanakan pelatihan hitung cepat integral melalui platform zoom 
4. Memberikan postest dalam bentuk google form

\section{HASIL DAN PEMBAHASAN}

Pelaksanaan kegiatan Program Kemitraan Masyarakat (PKM) dengan judul "Peningkatan Kompetensi Pembelajaran Matematika Melalui Rumus Cepat Integral Bagi Siswa MA Al Falak" tetap berlangsung dengan cukup baik meskipun tidak sesuai rencana di awal. Hal ini dikarenakan ketika mau melaksanakan kegiatan PKM ini terjadi pandemi covid19 yang menyebabkan MA Al Falak ditutup dan tidak melakukan proses belajar mengajar secara tatap muka. Sempat ada ijin dari kepala sekolah MA Al Falak kepada tim pelaksana kegiatan PKM untuk melaksanakan kegiatan ini secara tatap muka namun siswa yang diikutsertakan hanya 20 orang siswa dan 1 orang guru matematika karena ada peraturan selama pandemi tidak boleh berkerumun. Hal ini pun membuat para tim pelaksana begitu antusias menyiapkan peralatan yang diperlukan untuk melaksanakan kegiatan PKM sesuai dengan protokol kesehatan.

Tim pelaksana melakukan rapat pelaksanaan kegiatan PKM dan memutuskan untuk membeli face shield dan hand sanitizer untuk tim pelaksana, siswa dan guru pakai selama kegiatan berlangsung. Tim pelaksana juga mencetak modul dan membeli buku serta pulpen untuk hadiah siswa yang aktif pada saat pelaksanaan kegiatan PKM. Namun, takdir mengatakan lain, sehari sebelum rencana pelaksanaan kegiatan PKM secara tatap muka, wakil kepala sekolah bidang kesiswaan menghubungi ketua PKM dan memberikan kabar bahwa ada keluarga siswa MA Al Falak yang terserang virus covid19. Hal ini menyebabkan sekolah lagilagi ditutup dan wakil kepala sekolah meminta untuk membatalkan kegiatan PKM secara tatap muka. Pada saat itu, ketua PKM melakukan negosiasi untuk tetap memberikan ijin kepada tim pelaksana kegiatan PKM melaksanakan kegiatan ini tapi secara daring. Wakil Kepala sekolah pun setuju dan memberikan ijin kepada tim pelaksana melakukan kegiatan PKM secara daring, namun ia memberikan informasi juga bahwa keadaan ekonomi keluarga siswa MA Al Falak tergolong menengah ke bawah. Oleh karena itu, untuk bisa tetap terselenggara kegiatan PKM ini, tim Pelaksana memberikan subsidi pulsa untuk kuota internet pada guru dan siswa yang menjadi peserta kegiatan PKM.

Tim pelaksana kegiatan PKM pada akhirnya memutuskan untuk melakukan kegiatan PKM secara daring. Pihak Sekolah memberikan izin untuk pelaksanaan daring pada tanggal 22 Agustus 2020. Kegiatan PKM yang dilaksanakan secara daring, tentu mengubah tahapan pelaksanaan yang telah direncanakan di awal. Adapun tahapan pelaksanaan kegiatan PKM ini adalah sebagai berikut.

1. Memberikan Pretest dalam bentuk Google Form

2. Memberikan modul dalam bentuk PDF dan video pembelajaran untuk dipelajari terlebih dahulu oleh guru dan siswa sebelum dilakukan video confrence.

3. Melakukan pelatihan dengan cara tatap maya melalui video confrence menggunakan platform zoom.

4. Memberikan waktu kepada guru dan siswa untuk mempelajari lagi materi yang sudah diajarkan dan memberi kesempatan bertanya melakui platform WhatsApp

5. Memberikan postest dalam bentuk Google Form

6. Melakukan analisa hasil belajar untuk dilihat apakah terdapat perbedaan sebelum diberikan pelatihan dan sesudah pelatihan sehingga bisa terlihat apakah pelatihan ini dapat meningkatkan kompetensi pembelajaran matematika siswa khususnya pada materi integral atau tidak. 


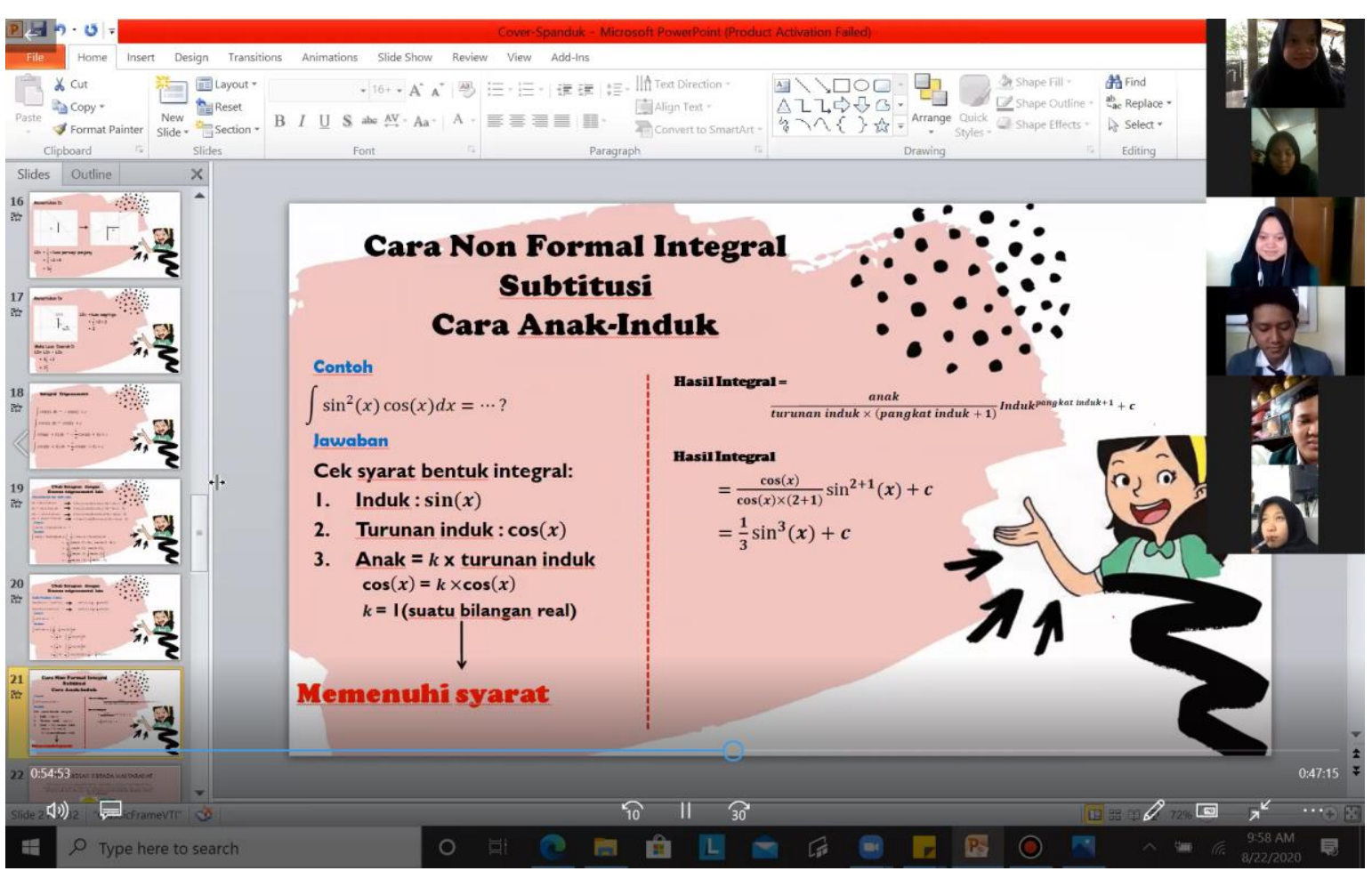

Gambar 1. Pelatihan Rumus Cepat Integral

Pertama sekali dilakukan uji varians dan uji normalitas pada dua kelompok data yaitu nilai pretest dan nilai posttest siswa. Uji varians dilakukan untuk menguji apakah siswa yang dipilih untuk mengikuti ini memiliki kondisi yang sama dan kemampuan yang sama. Sedangkan uji normalitas dilakukan untuk menguji apakah distribusi data berdistribusi normal atau tidak.

Test of Homogeneity of Variance

\begin{tabular}{|c|c|c|c|c|c|}
\hline & & $\begin{array}{l}\text { Levene } \\
\text { Statistic }\end{array}$ & df1 & df2 & Sig. \\
\hline \multirow[t]{4}{*}{ nilai } & Based on Mean & .041 & 1 & 38 & .841 \\
\hline & Based on Median & .051 & 1 & 38 & .823 \\
\hline & $\begin{array}{l}\text { Based on Median and } \\
\text { with adjusted df }\end{array}$ & .051 & 1 & 37.922 & .823 \\
\hline & Based on trimmed mean & .039 & 1 & 38 & .844 \\
\hline
\end{tabular}

Table 1. Output Uji Varians

Berdasarkan output uji varians dengan menggunakan bantuan software SPSS versi 24 pada Gambar 5, diperoleh tingkat signifikansi atau nilai probabilitas mean (rata-rata) yang berada di atas 0.05 yaitu 0.841 . Demikian pula jika dasar pengukuran adalah median data, angka signifikasinya 0.823 lebih dari 0.05 . Berdasarkan dua hasil tersebut, maka bisa dikatakan data berasal dari populasi yang mempunyai varians yang sama atau pretest dan posttest diambil dari siswa yang mempunyai kemampuan yang sama (homogen). 
Tests of Normality

\begin{tabular}{|c|c|c|c|c|c|c|c|}
\hline & \multirow[b]{2}{*}{ kelompok } & \multicolumn{3}{|c|}{ Kolmogorov-Smirnov ${ }^{a}$} & \multicolumn{3}{|c|}{ Shapiro-Wilk } \\
\hline & & Statistic & df & Sig. & Statistic & df & Sig. \\
\hline \multirow[t]{2}{*}{ nilai } & pretest & .169 & 20 & .137 & .922 & 20 & .107 \\
\hline & postest & .185 & 20 & .072 & .912 & 20 & .070 \\
\hline
\end{tabular}

a. Lilliefors Significance Correction

Tabel 2. Output Uji Normalitas

Pada Gambar 6, terlihat hasil uji normalitas menunjukkan baik nilai pretest maupun posttest, tingkat signifikasinya lebih dari 0.05. Signifikansi nilai pretest adalah 0.107 dan signifikansi nilai posttest adalah 0.07 . Berdasarkan signifikansi tersebut, dapat disimpulkan data nilai pretest dan posttest berdistribusi normal.

\begin{tabular}{|c|c|c|c|c|c|}
\hline \multicolumn{6}{|c|}{ Descriptives } \\
\hline & kelompo & & & Statistic & Std. Error \\
\hline \multirow[t]{26}{*}{ nilai } & \multirow[t]{13}{*}{ pretest } & Mean & & 31.0000 & 1.28759 \\
\hline & & \multirow{2}{*}{$\begin{array}{l}95 \% \text { Confidence Interval } \\
\text { for Mean }\end{array}$} & Lower Bound & 28.3050 & \\
\hline & & & Upper Bound & 33.6950 & \\
\hline & & $5 \%$ Trimmed Mean & & 31.1111 & \\
\hline & & Median & & 30.0000 & \\
\hline & & Variance & & 33.158 & \\
\hline & & Std. Deviation & & 5.75829 & \\
\hline & & Minimum & & 20.00 & \\
\hline & & Maximum & & 40.00 & \\
\hline & & Range & & 20.00 & \\
\hline & & Interquartile Range & & 10.00 & \\
\hline & & Skewness & & .028 & .512 \\
\hline & & Kurtosis & & -.774 & .992 \\
\hline & \multirow[t]{13}{*}{ postest } & Mean & & 80.7500 & 1.32163 \\
\hline & & \multirow{2}{*}{$\begin{array}{l}95 \% \text { Confidence Interval } \\
\text { for Mean }\end{array}$} & Lower Bound & 77.9838 & \\
\hline & & & Upper Bound & 83.5162 & \\
\hline & & $5 \%$ Trimmed Mean & & 80.8333 & \\
\hline & & Median & & 80.0000 & \\
\hline & & Variance & & 34.934 & \\
\hline & & Std. Deviation & & 5.91052 & \\
\hline & & Minimum & & 70.00 & \\
\hline & & Maximum & & 90.00 & \\
\hline & & Range & & 20.00 & \\
\hline & & Interquartile Range & & 10.00 & \\
\hline & & Skewness & & .106 & .512 \\
\hline & & Kurtosis & & -.964 & .992 \\
\hline
\end{tabular}

Tabel 3. Hasil Perhitungan Statistika Deskriptif

Berdasarkan hasil perhitungan statistika deskriptif pada Gambar 7, diperoleh nilai rata-rata siswa pada pretest yaitu 31, dengan nilai terendah 20 dan nilai tertingginya 40 . Hal ini menunjukkan bahwa rata-rata nilai pretest siswa lebih kecil dibandingkan nilai KKM yang ditetapkan guru yaitu 60. Ini menunjukkan, bahwa sebelum diberikan pelatihan, nilai rata-rata siswa masih dibawah KKM. Namun setelah diberikan pelatihan hitung cepat integral, nilai ratarata siswa meningkat menjadi 80.75, nilai terkecilnya 70 dan tertingginya adalah 90 . Berdasarkan perbandingan nilai rata-rata siswa sebelum dan sesudah diberikan pelatihan, dapat disimpulkan bahwa terjadi peningkatan yang signifikan. Akan tetapi, perlu diuji lebih lanjut 
dengan uji-t untuk dua data yang berpasangan sehingga bisa diketahui apakah ada perbedaan nilai antara sebelum dan sesudah pemberian pelatihan rumus cepat integral.

\begin{tabular}{|c|c|c|c|c|}
\hline \multicolumn{5}{|c|}{ Paired Samples Correlations } \\
\hline & & $\mathrm{N}$ & Correlation & Sig. \\
\hline Pair 1 & pretest \& postest & 20 & .905 & .000 \\
\hline
\end{tabular}

Tabel 4. Output paired sample correlations

Berdasarkan Gambar 8, pada output paired sample correlations terlihat hasil korelasi antara kedua variabel, yang menghasilkan angka 0.905 dengan nilai probabilitas 0.00 yang kurang dari 0.05 . Hal ini menyatakan bahwa korelasi antara nilai pretest dan postest adalah sangat erat dan benar-benar berhubungan secara nyata.

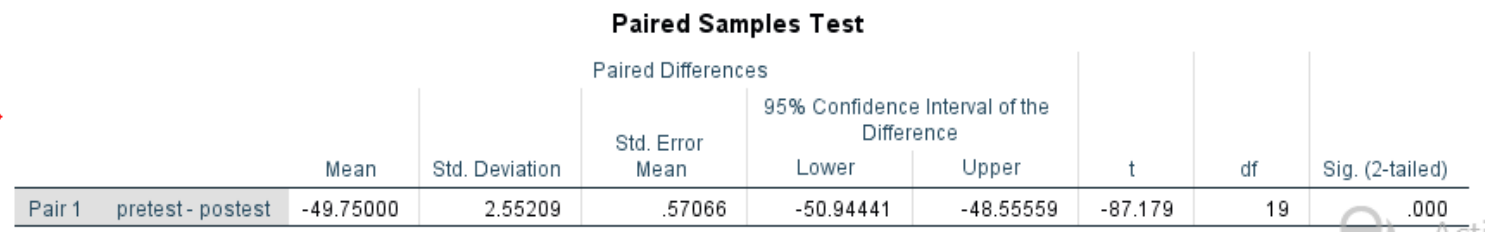

Gambar 6. Output Uji-t untuk dua data yang berpasangan

Berdasarkan perhitungan thitung dan t tabel

Jika statistik hitung (angka t output) > statistik tabel (tabel $\mathrm{t}$ ), maka $\mathrm{H}_{0}$ ditolak.

Jika statistik hitung (angka t output) < statistik tabel (tabel t), maka $\mathrm{H}_{0}$ diterima.

Nilai t hitung dari output berdasarkan Gambar 9 adalah -12.333.

Sedangkan statistik tabel dengan tingkat signifikansi 5\% untuk uji dua sisi, sehingga masingmasing sisi menjadi $2.5 \%$ dan dengan derajat kebebasan $20-1=19$ adalah $\mathrm{t}_{(0.025 ; 19)}=0.209302$. Keputusan:

Karena $\mathrm{t}_{\text {hitung }}=-87.179<-0.209302$ maka $\mathrm{t}_{\text {hitung }}$ terletak pada daerah $\mathrm{H}_{0}$ ditolak. Oleh karena itu, bisa disimpulkan ada perbedaan nilai antara sebelum dan sesudah pemberian pelatihan rumus cepat integral.

Berdasarkan nilai probabilitas

Jika probabilitas $>0.025$, maka $\mathrm{H}_{0}$ diterima.

Jika probabilitas $<0.025$, maka $\mathrm{H}_{0}$ ditolak.

Keputusan:

Nilai probabilitas berdasarkan Gambar 9 adalah 0. Untuk uji dua sisi, angka probabilitas adalah $0 / 2=0$. Karena nilai probabilitas dua sisi $=0<0.025$, maka $\mathrm{H}_{0}$ ditolak. Dapat disimpulkan bahwa ada perbedaan nilai antara sebelum dan sesudah pemberian pelatihan rumus cepat integral. Dengan kata lain, pelatihan rumus cepat integral efektif untuk meningkatkan kompetensi pembelajaran matematika siswa khususnya pada materi integral.

\section{KESIMPULAN DAN SARAN}

Kesimpulan hasil yang diperoleh dari pelaksanaan pelatihan rumus cepat integral adalah pelatihan rumus cepat integral efektif untuk meningkatkan kompetensi pembelajaran matematika siswa khususnya materi integral. Hal ini dikarenakan berdasarkan uji-t berpasangan dari data nilai pretest dan posttest siswa MA Al-Falak, diperoleh nilai thitung = $87.179<-\mathrm{t}_{\text {tabel }}=-0.209302$ sehingga $\mathrm{t}_{\text {hitung }}$ terletak pada daerah $\mathrm{H}_{0}$ ditolak. Oleh karena itu, 
bisa disimpulkan ada perbedaan nilai antara sebelum dan sesudah pemberian pelatihan rumus cepat integral. Selain itu, berdasarkan hasil perhitungan statistika deskriptif, diperoleh nilai rata-rata pretest siswa adalah 31 sedangkan nilai rata-rata posttest siswa adalah 80.75 yang mengartikan terjadi peningkatan hasil belajar yang signifikan.

Saran yang dapat diberikan adalah pelatihan rumus cepat integral dapat menjadi rekomendasi bagi para guru yang membutuhkan suatu metode ajar baru untuk mengajarkan materi integral sehingga dapat meningkatkan komepetensi belajar siswa khususnya pada materi integral.

\section{DAFTAR PUSTAKA}

Muhibbin. 2006. Psikologi Pendidikan dengan Pendekatan Baru. Remaja Rosdakarya : Bandung. 